\title{
A lexical database for Spanish-speaking children
}

\author{
ARMANDO PIÑEIRO \\ Cuban Neuroscience Center, Havana, Cuba \\ and \\ MAYRA MANZANO \\ University of Havana, Havana, Cuba
}

\begin{abstract}
This article presents a computerized database of words for use in experimental research in cognitive psychology and psycholinguistics. The data are based on the oral vocabulary of 200 Spanish-speaking children aged from 11.16 to 49.16 months. The database includes 15,428 Spanish words (tokens) and comprises 1,259 different words (types). It provides information about age of acquisition, orthography, grammar, semantics, and frequency.
\end{abstract}

Experimental tasks that use verbal materials require standardized pools of words, in order to avoid potential misinterpretations of the results. This need has generated studies whose objective has been the standardization of verbal material. Words have been standardized on a number of different variables that may have important effects on semantic and episodic memory, as well as on other cognitive processes. Some of these variables are frequency of occurrence (Freq; Carroll, Davies, \& Richman, 1971; Kučera \& Francis, 1967; Thorndike \& Lorge, 1944), age of acquisition (Aacq; Carroll \& White, 1973a, 1973b; Gilhooly \& Logie, 1980), familiarity (Gernsbacher, 1983), imagery, concreteness, and meaningfulness (Benjafield \& Muckenheim, 1989; Christian, Bickley, Tarka, \& Clayton, 1978).

The development of computers has facilitated the organization of word pools into databases (e.g., Coltheart, 1981; Content, Mousty, \& Radeau, 1990; Dale \& Fenson, 1996; Friendly, Franklin, Hoffman, \& Rubin, 1982; Wilson, 1988), allowing for faster and easier searches.

Most of the standardization work for verbal materials has been done in the English language. In the Spanish language, particularly, this kind of work is not frequently found (Dasí, 1986) and it is usually limited to adults (Alameda \& Cuetos, 1995; Algarabel, Ruiz, \& Sanmartín, 1988; Algarabel \& Sanmartín, 1985; Juilland \& ChangRodríguez, 1964; Manzano, Inguanzo, Piñeiro, \& Acen, 1999). For Spanish-speaking children, standardized verbal data either are scarce or have not been published. Researchers in this area have studied mainly the frequency of words written by school-age children, rather than the utterances of younger children (Casanova \& Rivera, 1989; Justicia, 1995).

The authors are grateful to Karla Villareal for her work in the implementation of the computer database. We also thank Alexis de la Cruz, Gonzalo Inguanzo, Vianca Chávez, and Jesús Núñez for their help in preparing this report. Correspondence concerning this article should be addressed to A. Piñeiro, Departamento de Neurociencias Cognitivas, Centro de Neurociencias de Cuba, Avenida 25 Esq. 158. Cubanacán, Playa, La Habana, Cuba AP 6880 (e-mail: armando@cneuro.edu.cu).
The purpose of this article is to describe a database obtained from the verbal utterances of a group of children under 5 years of age and to show the statistical analysis of some of the variables involved, in order to facilitate comparison with other databases. The variables included in our study are age of first time uttered (FTU), Aacq, Freq, number of letters (Nlett) and syllables (Nsyll), grammatical class (GClass), stress pattern (StrP), semantic category (SemCat), and orthographic consonant-vowel pattern (OCVP).

An important aspect of our work is that it fills a gap in current scientific research for such a widely used language as Spanish.

\section{METHOD}

\section{Subjects}

The subjects were 200 Cuban Spanish-speaking children (96 males), ranging in age from 11.16 to 49.16 months (mean = 24.03 months, $S D=10.14$ ). They were grouped by age in intervals of 2-4 months, so that each group was composed of 16-20 children. The groups were formed of different age intervals so that the number of children in each group would be approximately equal. The following groups (months.days) were used: 11.16-14.15, 14.16-17.15, $17.16-20.15,20.16-22.15,22.16-25.15,26.04-29.16,30.04-33.22$, $34.07-37.21,38.04-41.23,42.06-45.21$, and 46.03-49.16.

The subjects were selected from six day-care centers in four different municipalities of the city of Havana. The children included in the study had a normal development for their age, as reported by the nursery assistant. The risk of including a child with auditory problems was reduced by an interview with their parents. All the mothers had at least a high school educational level. The socioeconomic level of the families was average, representative of the general Cuban population.

Vocabulary size was not influenced by sex, socioeconomic level, or mother's education. The variables of interest (sex, socioeconomic status, and mother's education) have not influenced the results of the other studies that have investigated vocabulary size in young children. For example, in recent research (not yet published) in which we studied the vocabulary development of 605 children in western Cuba, we did not find any significant differences in the vocabulary size for the variables sex, attendance at nurseries, mothers' educational level, zone of residence (rural or urban), or mothers' occupation. Jackson-Maldonado, Thal, Marchman, Bates, and Gutierrez- 
Clellen (1993) did not find lexical differences related to sex or mother's educational level in their study with Mexican children.

\section{Materials and Procedure}

The words included in the database were obtained from the utterances produced by 200 children. The utterances were selected from the children's conversations with their peers and with the researchers.

The data were collected while the subject was in a room where he/she was able to play freely with toys (teddy bears, plastic toys, musical instruments, cars, balls, and the like), alone or with other children. In order to facilitate communication, the child was allowed to interact not only with his/her peers and the toys, but also with the two researchers in the room. Each observation lasted approximately $30 \mathrm{~min}$. A total of four observers (two of whom worked with children under 25.15 months, whereas the other two observed the older ones) made a literal transcription of the children's utterances.

An observation was excluded if the observers did not concur on the identity of the word. Approximately $7 \%$ of the utterances were rejected.

In most cases, word identification is not affected by the substitutions, omissions, translations, or the use of stable substitutes that are typical of this age group. For example, the omission of the phoneme /s/ in apato does not interfere with the recognition, within a given context, of the word zapato (shoes). When a child calls un reloj (a watch) a "tic-tac" or una pelota (a ball) a "pun pun," he/she is making use of a conventional form to name objects or actions (stable substitutes) that, although are not part of the vocabulary used by adults, can be recognized as words. Words that were considered as entries were those that both observers recognized as a word in the Spanish language.

The rejection rates were $12 \%$ for younger children (11.16-25.15 months) and $5 \%$ for the older group. A word was considered different if it appeared as a different entry, or type, in the dictionary. For instance, the different conjugations for the verb hacer (to do)-hago, hace, and so forth - were considered to be different types. The classification of each word was interpreted in context. In this way tiro (to throw) appears only as a verb (i.e., as a variation of the verb to throw), pesca (to fish) appears as a verb and not as a noun, dulce (candy) as a noun and not as an adjective, and the word mata (bush) appears twice-as a noun when it is a synonym for plant and as the verb to kill.

The software used to created the database was dBaseIII (AshtonTate, 1986). For each word, we included different variables that are frequently used in verbal tasks. The composition of the database is summarized in Table 1. The first column of the table provides the linguistic properties described in an entry, the second column specifies the identity of the linguistic property, and the third column indicates the number of types.

\section{Description of the Database}

Word. This is the name of each word included. The database has 15,428 tokens and 1,259 types.

Table 1

Composition of the Database

\begin{tabular}{llc}
\hline Name & \multicolumn{1}{c}{ Property } & Occurrence \\
\hline Wd & words & 1,259 \\
FTU & first time uttered & 1,259 \\
Aacq & age of acquisition & 298 \\
Nlett & number of letters in the word & 1,209 \\
Nsyll & number of syllables in the word & 1,209 \\
Freq & frequency & 1,259 \\
Gclass & grammatical class & 1,259 \\
StrP & stress pattern & 1,209 \\
SemCat & semantic categories & 447 \\
OCVP & consonant-vowel pattern & 1,209 \\
\hline
\end{tabular}

First time uttered. The FTU variable shows the age range in which at least 1 child produced the word for the first time.

Age of Acquisition. The age range in which the words cumulative frequency reaches $10 \%$ of its total frequency. This variable was calculated for words whose frequency is equal to or higher than 10 . In order to clarify the difference between the FTU and Aacq variables, we will use the word gato (cat) as an example. This word was produced for the first time by a child in the age group 14.16-17.15, which makes FTU $=14.16-17.15$. On the other hand, the total Freq for the same word is 38. For Aacq $=17.16-20.15$, the word gato has an Freq of 6, which represents $15 \%$ of the total Freq (38). In summary, the variable FTU indicates the age range within which a specific word may appear for the first time, whereas Aacq shows approximately the age at which the same word begins to acquire a determined meaning in the active vocabulary of the child.

Number of letters. The Nlett variable is the number of letters in each word.

Number of syllables. The Nsyll variable is the number of syllables in each word. We used the same syllabication algorithm as that published by Mañas (1987). Rules to syllabicate Spanish language words are stated by the Real Academia Española (1973).

Frequency. The Freq variable is the number of occurrences of each type.

Grammatical class. The GClass variable classifies the words by their grammatical role in speech. The observers took literal note of the children's verbalizations, pointing out in each case the context in which they were produced; this process made their classification easier in terms of grammatical functions.

Stress pattern. The StrP variable refers to the stressed syllable. In the Spanish language, StrPs are easily stated by means of a set of specific orthographic rules. Words called agudas are stressed in the last syllable, words called llanas are stressed in the penultimate syllable, and those called esdrujulas are stressed in the antepenultimate one.

Semantic category. Common nouns were classified according to their SemCats. A total of 23 categories were used, 12 of which were taken from the categories of Morenza et al. (1989) and Piñeiro, Morenza, Torres, and Sierra, (1999).

Orthographic consonant-vowel pattern. The letters that form each syllable were codified with the character $C$ (for consonant) or $\mathrm{V}$ (for vowel).

The FTU, Aacq, Nlett, Nsyll, and Freq variables are numeric, whereas the rest are characters. For compound words -those with a single meaning but made up of more than one word (e.g., por qué, why) - the following variables were not recorded: Nlett, Nsyll, StrP, and OCVP.

\section{RESULTS AND DISCUSSION}

Appendix A lists each word included in the database, along with FTU, Aacq, Nlett, Nsyll, Freq, and StrP. Appendix B shows stable substitutes and their FTU, Aacq, and Freq.

The most important results for each variable are presented below.

\section{First Time Uttered and Age of Acquisition}

Table 2 shows the number of types produced for the first time (FTU) in each age range. The number of children in each age group is also included.

Most words were produced during the interval of 22.16-25.15 months for both FTU and Aacq. At this period in life, which is called the vocabulary spurt, the rate of word acquisition is markedly accelerated (Goldfield 
Table 2

Range of First Time Uttered (FTU, in Months) and Distribution of Types

\begin{tabular}{ccc}
\hline FTU & $n$ & Types \\
\hline & Younger Group & \\
$11.16-14.15$ & 20 & 24 \\
$14.16-17.15$ & 20 & 25 \\
$17.16-20.15$ & 19 & 41 \\
$20.16-22.15$ & 20 & 75 \\
$22.16-25.15$ & 17 & 257 \\
& Older Group & 129 \\
$26.04-29.16$ & 18 & 151 \\
$30.04-33.22$ & 19 & 141 \\
$34.07-37.21$ & 17 & 146 \\
$38.04-41.23$ & 18 & 127 \\
$42.06-45.21$ & 16 & 143 \\
$46.03-49.16$ & 16 & \\
\hline
\end{tabular}

\& Reznick, 1990; McCarthy, 1946). After the age of 25.15 months, the number of types that children produces almost doubles. Since there appears to be an important change in their vocabulary between 22.15 and 25.15 months of age, for further analysis, we will continue to divide the sample into those younger than 25.15 months and those older than 25.16 months.

\section{Number of Letters}

Nlett ranged from 1 to 11 . Most words had 4 to 6 letters; the mean for Nlett was $5.71(S D=1.85)$.

\section{Number of Syllables}

Nsyll ranged from 1 to 5. Most words have two or three syllables $($ mean $=2.46, S D=0.82)$. These results seem to indicate that Spanish words are relatively long, and this can be seen even in the earliest Aacq. Although they have been obtained in different ways and with different subjects, our results coincide with those of Algarabel et al. (1988) with adult subjects, where the mean Nlett was 8.25 , and with those of Justicia (1995), who found a primacy of three-syllable words in a study of Freq in texts written by children.

\section{Frequency}

This value ranged from 1 to 444 (mean $=12.25, S D=$ 31.95 ). For 386 types ( $30.6 \%$ ), the frequency was 1 . For 31 types, Freq was greater than 100 . Some of these highfrequency words were open-class items $(51.6 \%)$ : nouns, verbs, verbal forms, adjectives, and adverbs-nené (baby), papá (daddy), dame (give me), mamá (mother), agua (water), and so forth. The rest were closed-class items (48.3\%): pronouns, prepositions, articles, interjections, numerals, conjunctions, and contractions-yo (I, me), mia (my, mine), esto (this), el (the), and so forth. As for the words' lengths some studies (e.g., Justicia, 1995) have reported similar results to ours.

\section{Grammatical Categories}

In order to analyze the results of this variable, the sample was split into two groups: younger (under 25.15 months, $n=96)$ and older (25.16 months and older, $n=$
104). Table 3 displays the 15 different syntactic categories that were used and the number of their occurrences. The words are categorized on the basis of first use only. The table also shows the number of types included in each GClass for the two groups of ages (younger and older), as well as for the total sample.

Nouns and verbs appear to be the most common words. Only 58 verbs $(15.06 \%)$ were produced in their infinitive form. Older children produced 51 of them. In Spanish, the infinitive forms of verbs have three endings: -ar (for instance, jugar, to play), -er (comer, to eat), and -ir (dormir, to sleep). In our database, the most frequent ending for the infinitive forms of verbs was - ar (found 39 times).

For younger children, the total number of conjugated verbs was 96. This number went up to 231 for the older group. The conjugated verbs were produced 265 times in the present tense. The verbs appeared 62 times in the past tense; they were only produced 10 times by children younger than 25.15 months and 52 times by those in the older group.

When the words were reclassified as open class and closed class, the results were as follows. For types, 1,189 were open-class words $(94.4 \%)$, and 70 were closed-class $(5.5 \%)$. For tokens, $10,722(69.4 \%)$ were open-class words, and 4,706 (30.5\%) were closed-class words, which supports our claim that closed-class words are the most widely used, even though they are the least represented in the vocabulary. Open-class words represented $89.6 \%$ ( 378 words), whereas closed-class words accounted for $10.4 \%$ (44 words) of the types in the younger group. For the older group, open-class words represented $96.8 \%$ (811 words) of the types, and closed-class words represented $3.10 \%$ ( 26 words).

\section{Stress Pattern}

Nine hundred and nine words were classified as llanas ( $75.1 \%$ of the total set of 1,209 types). The words called agudas were produced 264 times (21.8\%). The esdrúju-

Table 3

Number of Types First Used in Each Grammatical Category in Each Group

\begin{tabular}{lcrc}
\hline Grammatical Category & Younger & Older & Types \\
\hline Common nouns & 172 & 277 & 449 \\
Verbs & 103 & 182 & 385 \\
Proper nouns & 33 & 192 & 225 \\
Stable substitutes* & 40 & 6 & 46 \\
Adjectives & 13 & 18 & 31 \\
Pronouns & 20 & 11 & 31 \\
Adverbs & 14 & 13 & 27 \\
Gerunds & 3 & 18 & 21 \\
Prepositions & 4 & 5 & 9 \\
Articles & 4 & 5 & 9 \\
Interjections & 9 & 0 & 9 \\
Numerals & 5 & 3 & 8 \\
Past participles & 0 & 5 & 5 \\
Conjunctions & 1 & 1 & 2 \\
Contractions & 1 & 1 & 2 \\
\hline
\end{tabular}

Note-Younger, 25.15 months or less; older, more than 25.15 months. * Stable substitutes are a series of sounds naming an object that differ from the words adults produce - for example, miau (meow) instead of the word gato (cat) (Manzano, Perera, \& Correa, 1989). 
las words were found 36 times $(2.9 \%)$ only. These proportions match those in adult language: llanas, $69.37 \%$; agudas, 25.03\%; esdrújulas, 5.59\% (Manzano et al., 1999).

\section{Semantic Categories}

Table 4 shows the 23 categories into which types were classified, as well as the number of members of each category for those children under 25.15 months and for those older. Two words, goticas (little drop) and huequito (little hole), could not be classified in SemCats. The number of exemplars in each category and the percentage of the total sample (447) that they represented are also shown.

The categories with a greater number of instances were animal, person, food/beverage, and clothing article. These have been reported as the most inclusive and largest categories (Battig \& Montague, 1969; Pascual \& Musitu, 1980; Piñeiro et al., 1999; Posnansky, 1978). Some researchers have shown results similar to ours-for instance, when Nelson (1973) studied the emergence of the first 50 words in children, she found that words for food and beverages were the most frequently used, followed by animals' names. In decreasing order, these two categories are followed by clothing, toys, vehicles, and furniture. In one of our previous research studies (not yet published), when using an inventory equivalent to the Communicative Development Inventory words (Fenson et al., 1994), the words most frequently produced belonged to the categories of people, animals, food/beverages, and toys. In the case of animals, we cannot rule out the possible influence of the toys (stuffed animals, teddy bears, and the like) that the children were exposed to during observation. As for

Table 4

Semantic Categories of Common Nouns

\begin{tabular}{|c|c|c|c|c|}
\hline Categories & Younger & Older & $\begin{array}{c}\text { Number of } \\
\text { Different Words }\end{array}$ & $\%$ \\
\hline Animal & 35 & 30 & 65 & 14.54 \\
\hline Person & 25 & 36 & 59 & 13.64 \\
\hline Food and beverage & 13 & 25 & 38 & 8.50 \\
\hline Article of clothing & 7 & 27 & 34 & 7.60 \\
\hline Toy & 9 & 24 & 33 & 7.38 \\
\hline Type of vehicle & 15 & 13 & 28 & 6.26 \\
\hline Part of the human body & 9 & 19 & 28 & 6.26 \\
\hline Activity & 4 & 21 & 25 & 5.59 \\
\hline Place & 11 & 12 & 23 & 5.14 \\
\hline Article of furniture & 8 & 13 & 21 & 4.69 \\
\hline Kitchen utensil & 9 & 6 & 15 & 3.35 \\
\hline Reading material & 6 & 7 & 13 & 2.90 \\
\hline Tree and flower & 5 & 6 & 11 & 2.46 \\
\hline Part of a building & 1 & 9 & 10 & 2.23 \\
\hline Disease & 3 & 5 & 8 & 1.79 \\
\hline Part of animal body & 2 & 4 & 6 & 1.34 \\
\hline Musical instrument & 2 & 4 & 6 & 1.34 \\
\hline Heavenly body & 1 & 4 & 5 & 1.11 \\
\hline Unit of measure time & 1 & 4 & 5 & 1.11 \\
\hline Tool & 2 & 3 & 5 & 1.11 \\
\hline Cleaning utensil & 1 & 3 & 4 & 0.89 \\
\hline Weapon & 2 & 1 & 3 & 0.67 \\
\hline Mean of communication & 1 & 1 & 2 & 0.45 \\
\hline
\end{tabular}

Note-Younger, 25.15 months or less; older, more than 25.15 months. the rest of these categories, the children produced words that cannot be related to the toys in the room.

Other authors (Morenza et al., 1989) have reported a similar distribution of categories when using a productionparadigm technique with adults: animals $(12.46 \%)$, food/ beverages $(13.75 \%)$, clothing $(9.32 \%)$, vehicles $(3.37 \%)$, furniture $(6.51 \%)$, kitchenware $(8.06 \%)$, reading materials $(10.05 \%)$, musical instruments $(6.25 \%)$, tools $(9.7 \%)$, cleaning utensils $(4.58 \%)$, and means of communication $(7.72 \%)$.

\section{Orthographic Consonant-Vowel Patterns}

The words produced by children are formed by 596 different syllables. They are made up of 19 different combinations of OCVPs. The most frequent patterns are CVC (found in 191 syllables), CV (140), CVV (70), CCV (61), and CVVC (45). These five combinations were found in $85 \%$ of the syllables, which is congruent with other research done on written Spanish, where these five consonant-vowel combinations have been found to be the most frequent ones (Alvarez, Carreiras, $\&$ de Vega, 1992; Justicia, 1995).

\section{Correlation Among the Variables}

Table 5 presents the Pearson intercorrelation matrix for the five numeric variables. In the correlation analysis, we have taken the $\log 10$ of the raw Freq, because the distribution of Freq is highly skewed in the positive direction.

Nlett and Nsyll are highly correlated $(r=.87)$. FTU and Aacq also present a high and significant correlation. The FTU and Aacq correlation with word Freq is relatively small, although significant. Aacq and FTU correlate negatively with Freq, suggesting that the words that children use the most are learned at an early age. The correlation between word length (Nlett and Nsyll) and word Freq is relatively small and negative, suggesting that the shorter words are used more frequently than the longer ones. Even long words with high Freq are reduced - for instance, many children say bici (bike) more frequently than bicicleta (bicycle). Correlations between FTU and Aacq with word length are the lowest and are positive, which shows that longer words are acquired at a later age and that the shorter ones are learned earlier in life.

In summary, the computerized database presented here provides new information about Spanish words used by young children. The variables included in our database are among those most frequently used by experimental researchers to create word lists. Despite the fact that there are different regional variations in the Spanish language that may produce grammatical, semantic, and phonological differences; adding up to cultural, environmental, and regional characteristics, we hope that this database may be useful for researchers who work with Spanish speakers. It is logical to expect that some of our results-for example, proportion of open- and closed-class words - will be very similar among Spanish-speaking children of different cultures. Nevertheless, the issues of similarity and difference 
Table 5

Correlation Between Dependent Measures

\begin{tabular}{lccccc}
\hline \multicolumn{1}{c}{ Measure } & 1 & 2 & 3 & 4 & 5 \\
\hline 1 FTU & 1.00 & & & & \\
2 Aacq & $.74^{*}$ & 1.00 & & & \\
3 Nlett & $.21^{*}$ & $.30^{*}$ & 1.00 & & \\
4 Nsyll & $.13 \dagger$ & $.20 \dagger$ & $.87^{*}$ & 1.00 & \\
5 Log. Freq & $-.47^{*}$ & $-.22 \dagger$ & $-.26^{*}$ & $-.21^{*}$ & 1.00 \\
\hline
\end{tabular}

${ }^{*} p \leq .01 ;{ }^{\dagger} p \leq .05$.

represent empirical questions to be answered by future studies on the oral language of young children.

\section{REFERENCES}

Alameda, J. R., \& Cuetos, F. (1995). Diccionario de frecuencias de las unidades lingüisticas del castellano [Frequency dictionary of Spanish words]. Oviedo: Universidad de Oviedo, Servicio de Publicaciones.

Algarabel, S., Ruiz, J. C., \& Sanmartín, J. (1988). The University of Valencia's computerized word pool. Behavior Research Methods, Instruments, \& Computers, 20, 398-403.

Algarabel, S., \& Sanmartín, J. (1985). BASPal: Descripción de la base computarizada de palabras de la Universidad de Valencia [Description of the University of Valencia's computerized database]. Psicológica, 6, 189-200.

Alvarez, C. J., Carreiras, M., \& DE Vega, M. (1992). Estudio estadístico de la ortografia castellana: 1. La frecuencia silábica [Statistical study of Castilian orthography: 1 syllable frequency]. Cognitiva 4, 75-105.

Ashton-Tate (1986). dBase III Plus 1.1. Culver City, CA: Author.

BatTig, W. F., \& MonTague, W. E. (1969). Category norms for verbal items in 56 categories: A replication and extension of the Connecticut category norms. Journal of Experimental Psychology Monographs, 80, 1-46.

Benjafield, J., \& Muckenheim, R. (1989). Dates of entry and measures of imagery, concreteness, goodness, and familiarity for 1,046 words sampled from the Oxford English Dictionary. Behavior Research Methods, Instruments, \& Computers, 21, 31-52.

Carroll, J. B., Davies, P., \& Richman, B. (1971). Word frequency book. Boston: Houghton Mifflin.

Carroll, J. B., \& White, M. N. (1973a). Age-of-acquisition norms for 220 picturable nouns. Journal of Verbal Learning \& Verbal Behavior, 12, 563-576.

Carroll, J. B. \& White, M. N. (1973b). Word frequency and age of acquisition as determiners of picture-naming latency. Quarterly Journal of Experimental Psychology, 25, 85-95.

Casanova, M. A., \& Rivera, M. (1989). Vocabulario básico en la E. G. B. [Basic vocabulary in the primary school]. Madrid, M. E. C./EspasaCalpe.

Christian, J., Bickley, W., Tarka, M., \& Clayton, K. (1978). Measures of free recall of 900 English nouns: Correlations with imagery, concreteness, meaningfulness, and frequency. Memory \& Cognition, 6, 379-390.

Coltheart, M. (1981). The MRC Psycholinguistic Database. Quarterly Journal of Experimental Psychology, 33A, 497-505.

Content, A., Mousty, P., \& Radeau, M. (1990). Brulex: Une base de données lexicales informatisée pour le Français écrit et parlé [Lexical database for spoken and written French]. L'Année Psychologique, 90, $551-566$

Dale, P. S., \& Fenson, L. (1996). Lexical development norms for young children. Behavior Research Methods, Instruments, \& Computers, 28, 125-127.

DAsí, C. (1986). Guía de Indices y Datos normativos sobre material verbal [Guides of normative data on verbal material]. Psicológica, 7, 99-102.
Fenson, L., Dale, P. S., Reznick, J. S., Bates, E., Thal, D., \& PETHICK, S. J. (1994). Variability in early communicative development. Monographs of the Society for Research in Child Development, 59 (Serial No. 242).

Friendly, M., Franklin, P. E., Hoffman, D., \& Rubin, D. C. (1982). The Toronto Word Pool: Norms for imagery, concreteness, orthographic variables, and grammatical usage for 1,080 words. Behavior Research Methods \& Instrumentation, 14, 375-399.

GernsBacher, M. A. (1983, April). The experimental familiarity norms and their psychological validity. Paper presented at the 29th Annual Meeting of the Southwestern Psychological Association, San Antonio.

Gilhooly, K. J., \& Logie, R. H. (1980). Age-of-acquisition, imagery, concreteness, familiarity, and ambiguity measures for 1,944 words. Behavior Research Methods \& Instrumentation, 12, 395-427.

Goldfield, B. A., \& ReznICK, J. S. (1990). Early lexical acquisition: Rate, content, and the vocabulary spurt. Journal of Child Language, 17, 171-183.

Jackson-Maldonado, D., Thal, D., Marchman, V., Bates, E., \& GUTIERREZ-CLELLEN, V. (1993). Early lexical development in Spanishspeaking infants and toddlers. Journal of Child Language, 20, 523549.

Juilland, A., \& Chang-Rodríguez, E. (1964). Frequency dictionary of Spanish words. London: Mouton.

Justicia, F. (1995). El desarrollo del vocabulario. Diccionario de frecuencias [Vocabulary development. Frequency dicionary]. Granada: Monográfica Universidad de Granada.

KUČERA, H., \& FRANCIS, W. (1967). Computational analysis of presentday American English. Providence, RI: Brown University Press.

Mañas, J. A. (1987). Word division in Spanish. Communications of the $A C M, 30,612-616$.

Manzano, M., Inguanzo, G., Piñeiro, A., \& Acen, J. (1999). Diccionario de frecuencia de uso para adultos [Frequency dictionary for adults]. Unpublished manuscript, University of Havana, Department of Psychology.

Manzano, M., Perera, M., \& Correa, S. (1989). Acerca de la construcción de un instrumento para evaluar el desarrollo del lenguaje (IDL) [A tool for assessment of language development]. Revista Cubana de Psicología, 10, 77-83.

MCCARTHY, D. (1946). Language development in children. In L. Carmichael (Ed.), Manual of child psychology (pp. 476-581). New York: Wiley.

Morenza, L., Torres, R., Chivas, F., Riera, J., Lara, I., Biscay, R., Galán, L., Santaya, M., \& Castellanos, D. (1989, Month). Natural categories during ontogeny: Relevance for the structure of semantic memory. Paper presented at International Conference Advanced Methods in Neuroscience, Havana.

Nelson, K. (1973). Structure and strategy in learning to talk. Monographs of the Society of Research in Child Development, 38 (Serial No. 149).

Pascual, J., \& Musitu, G. (1980). Normas categoriales [Category norms]. Psicológica, 1, 157-174.

Piñeiro, A., Morenza, L., Torres, R., \& Sierra, C. E. (1999). Estudio normativo de veinte categorias semánticas en niños y adultos [Category norms for children and adults]. Revista de Psicologia General y Aplicada, 52, 147-157.

PoSNANSKY, C. J. (1978). Category norms for verbal items in 25 categories for children in Grades 2-6. Behavior Research Methods \& Instrumentation, 10, 819-832.

Real ACADEmia EsPañola (1973). Esbozo de una nueva gramática de la lengua Española [A new grammar of the Spanish language]. Madrid: Espasa-Calpe.

Thorndike, E. L., \& LoRgE, I. (1944). The teacher's word book of 30,000 words. New York: Teachers College Press.

WILSON, M. (1988). MRC Psycholinguistic Database: Machine-usable dictionary, version 2.00. Behavior Research Methods, Instruments, \& Computers, 20, 6-10. 
APPENDIX A

Words Included in the Database and First Time Uttered (FTU), Age of Acquisition (Aacq), Number of Letters (Nlett), Number of Syllables (Nsyll), Frequency (Freq), and Stress Pattern (StrP)

\begin{tabular}{|c|c|c|c|c|c|c|c|c|c|c|c|c|c|}
\hline Word & FTU & Aacq & Nlett & Nsyll & Freq & StrP & Word & FTU & Aacq & Nlett & Nsyll & Freq & StrP \\
\hline \multicolumn{7}{|c|}{ COMMON NOUNS } & jicoteita & $\mathrm{j}$ & & 9 & 4 & 4 & $\mathrm{~L}$ \\
\hline Activities & & & & & & & jirafa & $\mathrm{f}$ & & 6 & 3 & 1 & $\mathrm{~L}$ \\
\hline actividad & $\mathrm{j}$ & & 9 & 4 & 4 & A & lagartija & $\mathrm{h}$ & & 9 & 4 & 1 & $\mathrm{~L}$ \\
\hline besito & $\begin{array}{l}\mathrm{f} \\
\mathrm{f}\end{array}$ & $\mathrm{f}$ & 6 & 3 & 18 & $\mathrm{~L}$ & lechuza & $\mathrm{d}$ & & 7 & 3 & 2 & $\mathrm{~L}$ \\
\hline brigada & $\mathrm{j}$ & & 7 & 3 & 1 & $\mathrm{~L}$ & león & $\mathrm{e}$ & & 4 & 2 & 1 & A \\
\hline canción & $\mathrm{g}$ & & 7 & 2 & 3 & $\mathrm{~A}$ & lobo & $\mathrm{i}$ & & 4 & 2 & 5 & $\mathrm{~L}$ \\
\hline carnavales & $\mathrm{j}$ & & 10 & 4 & 2 & $\mathrm{~L}$ & mariposa & c & & 8 & 4 & 4 & $\mathrm{~L}$ \\
\hline comparsa & $\mathrm{g}$ & & 8 & 3 & 1 & $\mathrm{~L}$ & mariposita & $\mathrm{g}$ & g & 10 & 5 & 14 & $\mathrm{~L}$ \\
\hline cuento & $\begin{array}{l}8 \\
\mathrm{~g}\end{array}$ & & 6 & 2 & 5 & $\mathrm{~L}$ & mono & d & $\mathrm{e}$ & 4 & 2 & 14 & $\mathrm{~L}$ \\
\hline cumpleaños & f & f & 10 & 4 & 38 & $\mathrm{~L}$ & monos & $\mathrm{g}$ & & 5 & 2 & 3 & $\bar{L}$ \\
\hline fiesta & $\mathrm{e}$ & $\mathrm{i}$ & 6 & 2 & 10 & $\mathrm{~L}$ & mosquito & $\mathrm{k}$ & & 8 & 3 & 1 & $\mathrm{~L}$ \\
\hline fin & $\mathrm{i}$ & & 3 & 1 & 1 & A & osito & d & e & 5 & 3 & 22 & $\mathrm{~L}$ \\
\hline foto & f & $\mathrm{i}$ & 4 & 2 & 13 & $\mathrm{~L}$ & oso & $\mathrm{e}$ & $\mathrm{i}$ & 3 & 2 & 19 & $\mathrm{~L}$ \\
\hline golpe & $\mathrm{i}$ & & 5 & 2 & 7 & $\mathrm{~L}$ & pajarito & $\mathrm{d}$ & & 8 & 4 & 9 & $\mathrm{~L}$ \\
\hline guerra & $\mathrm{f}$ & & 6 & 2 & 2 & $\mathrm{~L}$ & pájaro & $\mathrm{e}$ & & 6 & 3 & 2 & E \\
\hline mentira & $\mathrm{k}$ & & 7 & 3 & 2 & L & palomita & $\mathrm{j}$ & & 8 & 4 & 2 & $\mathrm{~L}$ \\
\hline miedo & $\mathrm{h}$ & & 5 & 2 & 1 & $\mathrm{~L}$ & patico & $\mathrm{g}$ & & 6 & 3 & 4 & $\mathrm{~L}$ \\
\hline música & $\mathrm{j}$ & & 6 & 3 & 3 & $\mathrm{E}$ & pato & $\mathrm{b}$ & d & 4 & 2 & 47 & $\mathbf{L}$ \\
\hline natación & $\mathrm{j}$ & & 8 & 3 & 1 & A & pecesito & $\mathrm{e}$ & e & 8 & 4 & 13 & $\mathbf{L}$ \\
\hline paz & $\mathrm{f}$ & & 3 & 1 & 2 & A & pecesitos & $\mathrm{d}$ & & 9 & 4 & 3 & L \\
\hline preescolar & $\mathrm{k}$ & & 10 & 4 & 1 & A & perra & $\mathrm{e}$ & & 5 & 2 & 3 & $\mathrm{~L}$ \\
\hline pregunta & $\mathrm{k}$ & & 8 & 3 & 6 & $\mathrm{~L}$ & perrita & $\mathbf{k}$ & & 7 & 3 & 2 & $\mathrm{~L}$ \\
\hline preguntas & $\mathrm{k}$ & & 9 & 3 & 1 & $\mathrm{~L}$ & perrito & $\mathrm{e}$ & $\mathrm{h}$ & 7 & 3 & 28 & $\mathbf{L}$ \\
\hline respuesta & $\mathrm{k}$ & & 9 & 3 & 2 & $\mathrm{~L}$ & perro & b & e & 5 & 2 & 70 & $\mathbf{L}$ \\
\hline sed & $\mathrm{d}$ & & 3 & 1 & 2 & $\mathrm{~A}$ & pescadito & $\mathrm{e}$ & $\mathrm{f}$ & 9 & 4 & 10 & $\mathbf{L}$ \\
\hline trabajo & $\mathrm{e}$ & $\mathrm{h}$ & 7 & 3 & 50 & $\mathrm{~L}$ & pescaditos & $\mathrm{i}$ & & 10 & 4 & 5 & $\bar{L}$ \\
\hline vacaciones & $\mathrm{f}$ & & 10 & 4 & 6 & $\mathrm{~L}$ & pescado & d & $\mathrm{h}$ & 7 & 3 & 15 & $\mathbf{L}$ \\
\hline Animals & & & & & & & pingüino & $\mathrm{e}$ & & 8 & 3 & 1 & $\mathrm{~L}$ \\
\hline animal & $\mathrm{k}$ & & 6 & 3 & 5 & A & pollito & d & d & 7 & 3 & 23 & $\bar{L}$ \\
\hline animalito & $\hat{h}$ & & 9 & 5 & 6 & $\mathrm{~L}$ & pollo & $\mathrm{e}$ & & 5 & 2 & 8 & $\mathbf{L}$ \\
\hline araña & $\mathrm{g}$ & & 5 & 3 & 2 & $\mathrm{~L}$ & rana & d & e & 4 & 2 & 13 & $\mathbf{L}$ \\
\hline ardilla & e & & 7 & 3 & 3 & $\mathrm{~L}$ & ratón & e & & 5 & 2 & 5 & $\bar{A}$ \\
\hline ardillita & $\mathrm{g}$ & & 9 & 4 & 1 & $\mathrm{~L}$ & vaca & d & d & 4 & 2 & 10 & $\mathrm{~L}$ \\
\hline bicho & d & & 5 & 2 & 2 & $\mathrm{~L}$ & Articles of Clo & ling & & & & & \\
\hline caballito & f & $\mathrm{f}$ & 9 & 4 & 11 & $\mathrm{~L}$ & arete & $\mathrm{g}$ & g & 5 & 3 & 10 & $\mathrm{~L}$ \\
\hline caballo & $\mathrm{b}$ & $\mathrm{d}$ & 7 & 3 & 59 & $\mathrm{~L}$ & bata & $\mathrm{h}$ & & 4 & 2 & 4 & L \\
\hline caballos & $\mathrm{i}$ & & 8 & 3 & 5 & $\mathrm{~L}$ & batica & $\mathrm{e}$ & & 6 & 3 & 1 & $\mathrm{~L}$ \\
\hline cangrejito & $\mathrm{j}$ & & 10 & 4 & 3 & $\mathrm{~L}$ & blumer & $\mathrm{i}$ & & 6 & 2 & 5 & A \\
\hline cangrejo & $\mathrm{J}$ & & 8 & 3 & 7 & $\mathrm{~L}$ & blusita & g & & 7 & 3 & 3 & $\mathrm{~L}$ \\
\hline caracol & $\mathrm{g}$ & & 7 & 3 & 3 & A & cartera & $\mathrm{g}$ & g & 7 & 3 & 21 & L \\
\hline caracoles & $\mathrm{h}$ & & 9 & 4 & 4 & $\mathrm{~L}$ & cestica & $\mathrm{g}$ & & 7 & 3 & 1 & L \\
\hline caracolitos & $\mathrm{g}$ & & 11 & 5 & 1 & $\mathrm{~L}$ & cinto & g & & 5 & 2 & 1 & $\mathrm{~L}$ \\
\hline chiva & $\mathrm{h}$ & & 5 & 2 & 1 & L & collarito & $\mathbf{j}$ & & 9 & 4 & 2 & $\mathrm{~L}$ \\
\hline cochinita & f & & 9 & 4 & 2 & $\mathrm{~L}$ & hilo & $\mathrm{h}$ & & 4 & 2 & 1 & L \\
\hline cochinito & $\mathrm{j}$ & & 9 & 4 & 3 & $\mathrm{~L}$ & jaba & $\mathrm{j}$ & & 4 & 2 & 3 & $\mathrm{~L}$ \\
\hline cochino & $\mathrm{d}$ & & 7 & 3 & 3 & L & jabita & $\mathrm{f}$ & $f$ & 6 & 3 & 10 & $\mathrm{~L}$ \\
\hline cocodrilo & j & & 9 & 4 & 1 & $\mathrm{~L}$ & lazo & k & & 4 & 2 & 2 & $\mathrm{~L}$ \\
\hline conejito & $\begin{array}{l}\mathrm{J} \\
\mathrm{c}\end{array}$ & & 8 & 4 & 1 & L & maleta & h & & 6 & 3 & 3 & $\mathrm{~L}$ \\
\hline conejo & d & $\mathrm{d}$ & 6 & 3 & 11 & $\mathrm{~L}$ & medias & $\mathrm{j}$ & $\mathrm{j}$ & 6 & 2 & 16 & $\mathrm{~L}$ \\
\hline cucaracha & $\mathrm{i}$ & & 9 & 4 & 2 & $\mathrm{~L}$ & mosquitero & $\mathrm{k}$ & & 10 & 4 & 2 & $\mathrm{~L}$ \\
\hline cucarachita & $\mathrm{e}$ & & 11 & 5 & 5 & $\mathrm{~L}$ & pañoleta & $\mathrm{j}$ & & 8 & 4 & 3 & $\mathbf{L}$ \\
\hline elefante & $\mathrm{g}$ & & 8 & 4 & 6 & $\begin{array}{l}\mathrm{L} \\
\mathrm{L}\end{array}$ & pantalón & $\mathrm{i}$ & & 8 & 3 & 1 & $\mathrm{~A}$ \\
\hline gallina & $\begin{array}{l}\mathrm{g} \\
\mathrm{d}\end{array}$ & & 7 & 3 & 4 & $\mathrm{~L}$ & pipa & $\mathrm{e}$ & & 4 & 2 & 3 & $\mathbf{L}$ \\
\hline gallito & $\mathrm{e}$ & & 7 & 3 & 2 & $\mathrm{~L}$ & popis & $\mathrm{g}$ & & 5 & 2 & 1 & $\mathbf{L}$ \\
\hline gallo & d & $\mathrm{d}$ & 5 & 2 & 10 & $\begin{array}{l}\mathrm{L} \\
\mathrm{L}\end{array}$ & pulso & $i$ & & 5 & 2 & 1 & $\mathbf{L}$ \\
\hline gatico & $\mathrm{e}$ & $\mathrm{f}$ & 6 & 3 & 12 & $\mathrm{~L}$ & reloj & a & d & 5 & 2 & 13 & A \\
\hline gato & b & $\mathrm{c}$ & 4 & 2 & 38 & $\mathrm{~L}$ & ropa & h & & 4 & 2 & 5 & $\mathrm{~L}$ \\
\hline gatos & $\mathrm{i}$ & & 5 & 2 & 1 & $\mathrm{~L}$ & saya & $\mathrm{f}$ & & 4 & 2 & 3 & $\mathbf{L}$ \\
\hline hormiguita & $\mathrm{i}$ & & 10 & 4 & $\begin{array}{l}1 \\
5\end{array}$ & L & sombrero & d & & 8 & 3 & 2 & $\mathrm{~L}$ \\
\hline jicotea & $\mathrm{e}$ & & $\begin{array}{r}10 \\
7\end{array}$ & $\begin{array}{l}4 \\
4\end{array}$ & 5 & $\mathrm{~L}$ & sombrilla & $\mathrm{i}$ & & 9 & 3 & 1 & $\mathrm{~L}$ \\
\hline
\end{tabular}


APPENDIX A (Continued)

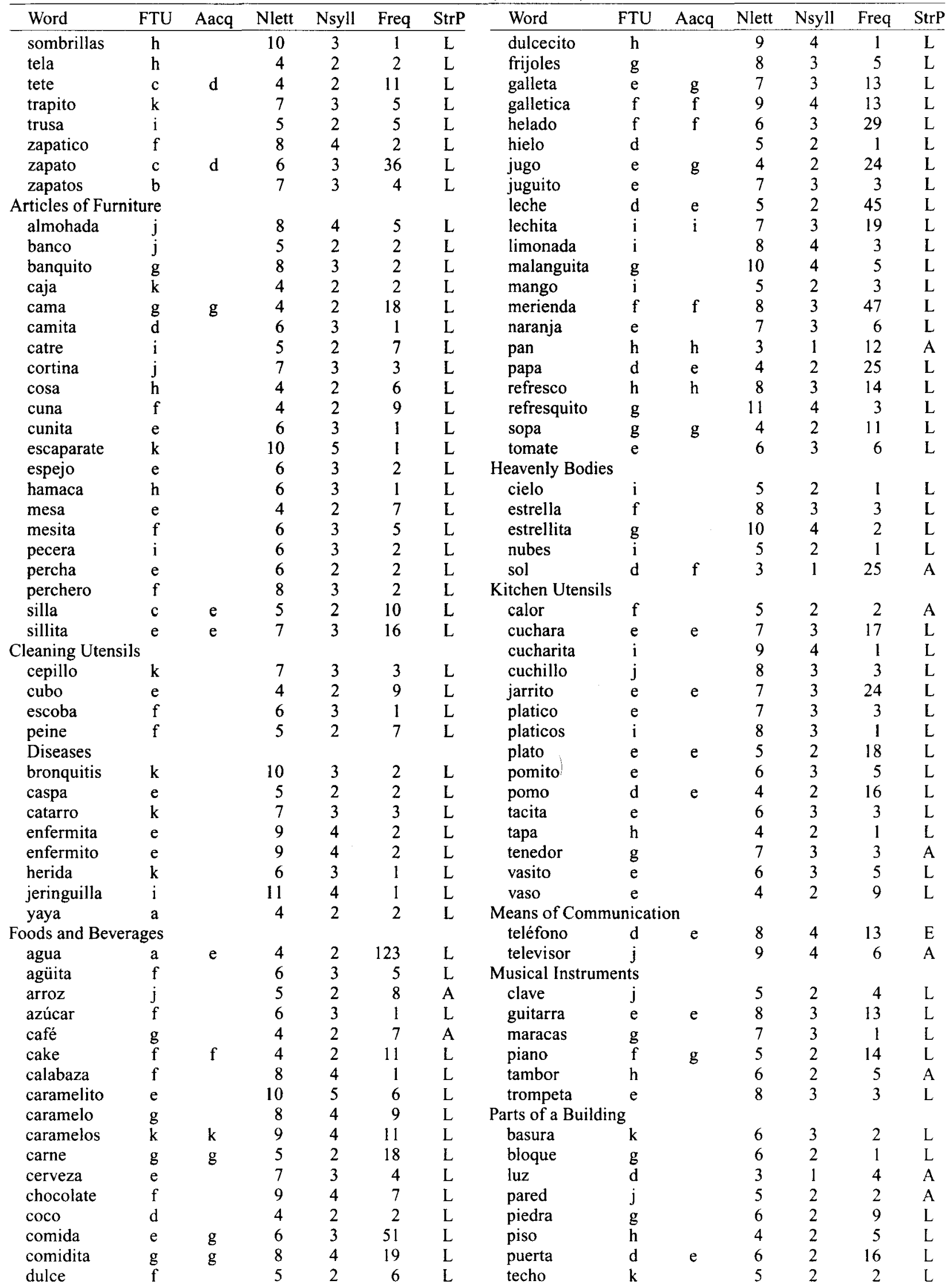


APPENDIX A (Continued)

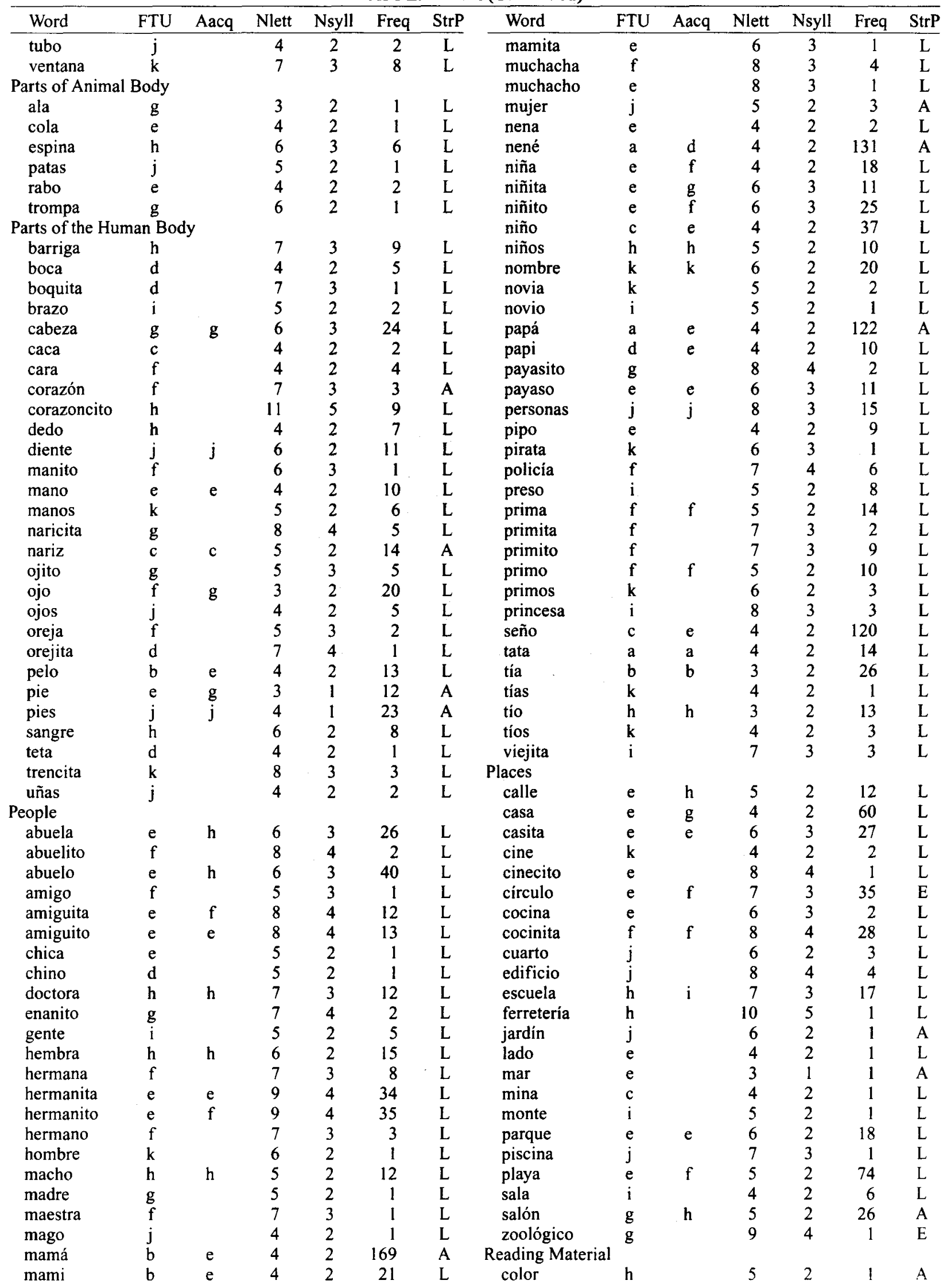


APPENDIX A (Continued)

\begin{tabular}{|c|c|c|c|c|c|c|c|c|c|c|c|c|c|}
\hline Word & FTU & Aacq & Nlett & Nsyll & Freq & StrP & Word & FTU & Aacq & Nlett & Nsyll & Freq & StrP \\
\hline colores & $\mathrm{e}$ & $\mathrm{i}$ & 7 & 3 & 13 & $\overline{\mathrm{L}}$ & tabaco & $\mathrm{c}$ & & 6 & 3 & 2 & $\mathrm{~L}$ \\
\hline crayola & $\mathbf{g}$ & & 7 & 3 & 3 & $\mathrm{~L}$ & yerba & $\mathrm{e}$ & & 5 & 2 & 1 & $\mathrm{~L}$ \\
\hline dibujitos & $\stackrel{o}{j}$ & & 9 & 4 & 1 & $\mathrm{~L}$ & Types of Vehicles & & & & & & \\
\hline dibujos & $\mathrm{k}$ & & 7 & 3 & 4 & L & ambulancia & $\mathbf{j}$ & & 10 & 4 & 1 & $\mathrm{~L}$ \\
\hline lámina & $j$ & & 6 & 3 & 6 & E & avión & $\mathrm{c}$ & d & 5 & 2 & 29 & A \\
\hline lápiz & $\mathrm{e}$ & & 5 & 2 & 9 & L & avioncito & $\mathrm{i}$ & & 9 & 4 & 2 & L \\
\hline libreta & e & & 7 & 3 & 2 & $\mathrm{~L}$ & barco & e & $\mathbf{g}$ & 5 & 2 & 11 & $\mathrm{~L}$ \\
\hline libretica & $\mathrm{e}$ & & 9 & 4 & 3 & L & barquito & e & $\mathrm{f}$ & 8 & 3 & 15 & $\mathrm{~L}$ \\
\hline librito & $\mathrm{e}$ & & 7 & 3 & 8 & L & camión & d & e & 6 & 2 & 35 & A \\
\hline libro & $\mathrm{j}$ & $\mathbf{j}$ & 5 & 2 & 12 & $\mathrm{~L}$ & camioncito & $\mathrm{e}$ & & 10 & 4 & 8 & $\mathrm{~L}$ \\
\hline papel & $\mathrm{c}$ & & 5 & 2 & 6 & A & camiones & $k$ & & 8 & 3 & 2 & $\mathrm{~L}$ \\
\hline pluma & $\mathbf{g}$ & & 5 & 2 & 1 & L & carro & e & e & 5 & 2 & 23 & $\mathrm{~L}$ \\
\hline Tools & & & & & & & carroza & $\mathrm{j}$ & & 7 & 3 & 3 & $\mathrm{~L}$ \\
\hline escalera & $\mathrm{e}$ & & 8 & 4 & 4 & L & chapa & $\mathrm{j}$ & & 5 & 2 & 4 & L \\
\hline escaleras & $\mathrm{j}$ & & 9 & 4 & 3 & $\mathbf{L}$ & coche & $\mathrm{e}$ & $\mathrm{h}$ & 5 & 2 & 11 & L \\
\hline pala & $\mathrm{e}$ & & 4 & 2 & 2 & L & grúa & $\mathbf{g}$ & & 4 & 2 & 8 & L \\
\hline pincho & $\mathrm{f}$ & & 6 & 2 & 1 & L & guagua & $\mathrm{b}$ & f & 6 & 2 & 29 & $\mathrm{~L}$ \\
\hline tijera & $\mathrm{j}$ & & 6 & 3 & 2 & L & guaguita & $\mathrm{g}$ & & 8 & 3 & 1 & L \\
\hline Toys & & & & & & & helicóptero & $\mathrm{g}$ & & 11 & 5 & 5 & E \\
\hline aparatico & g & & 9 & 5 & 1 & L & lada & $\mathrm{e}$ & & 4 & 2 & 1 & L \\
\hline arena & $\stackrel{i}{\mathrm{i}}$ & & 5 & 3 & 8 & $\bar{L}$ & máquina & $\mathrm{e}$ & & 7 & 3 & 6 & $\mathrm{E}$ \\
\hline bicicleta & $\mathrm{i}$ & & 9 & 4 & 8 & L & maquinita & e & & 9 & 4 & 6 & L \\
\hline bicicletica & $\mathrm{f}$ & $\mathrm{i}$ & 11 & 5 & 13 & L & moto & $\mathrm{e}$ & e & 4 & 2 & 12 & L \\
\hline bolas & $\mathrm{k}$ & & 5 & 2 & 4 & L & motorcito & $\mathrm{h}$ & $\mathrm{h}$ & 9 & 4 & 10 & $\mathrm{~L}$ \\
\hline bolita & $\mathbf{g}$ & & 6 & 3 & 7 & L & rastra & $\mathrm{i}$ & & 6 & 2 & 5 & L \\
\hline bolo & $\mathrm{h}$ & & 4 & 2 & 4 & L & rueda & e & g & 5 & 2 & 16 & $\mathrm{~L}$ \\
\hline carriola & e & & 8 & 3 & 1 & $\mathrm{~L}$ & ruedas & $\mathrm{i}$ & & 6 & 2 & 2 & L \\
\hline carrito & e & e & 7 & 3 & 19 & $\mathrm{~L}$ & timón & $\mathrm{i}$ & & 5 & 2 & 4 & $\mathrm{~A}$ \\
\hline cubito & $\mathbf{j}$ & & 6 & 3 & 4 & L & tractor & e & & 7 & 2 & 2 & A \\
\hline escopetica & f & & 10 & 5 & 5 & L & tren & d & d & 4 & 1 & 24 & A \\
\hline globo & $f$ & & 5 & 2 & 1 & L & trencito & h & & 8 & 3 & 4 & $\mathrm{~L}$ \\
\hline globos & $\mathrm{k}$ & & 6 & 2 & 4 & $\mathbf{L}$ & Units of Measure & & & & & & \\
\hline jueguito & i & & 8 & 3 & 3 & $\mathrm{~L}$ & años & $\mathrm{f}$ & & 4 & 2 & 1 & L \\
\hline juguete & c & $\mathrm{f}$ & 7 & 3 & 56 & L & dia & $\mathrm{i}$ & & 3 & 2 & 8 & $\mathrm{~L}$ \\
\hline juguetes & $\mathrm{h}$ & $\mathrm{i}$ & 8 & 3 & 13 & L & noche & $\mathrm{i}$ & & 5 & 2 & 1 & L \\
\hline juguetico & $\mathrm{e}$ & $\mathrm{e}$ & 9 & 4 & 17 & L & sábado & $\mathrm{j}$ & & 6 & 3 & 1 & $\mathrm{E}$ \\
\hline muñeca & d & $\mathrm{e}$ & 6 & 3 & 72 & L & tarde & $\mathrm{e}$ & & 5 & 2 & 1 & L \\
\hline muñecas & $\mathrm{k}$ & & 7 & 3 & 2 & L & Weapons & & & & & & \\
\hline muñeco & d & & 6 & 3 & 1 & L & bala & $\mathrm{e}$ & & 4 & 2 & 3 & L \\
\hline muñecos & k & & 7 & 3 & 2 & L & escopeta & $\mathrm{g}$ & & 8 & 4 & 5 & $\mathrm{~L}$ \\
\hline muñequita & $\mathbf{g}$ & $\mathrm{g}$ & 9 & 4 & 18 & $\mathbf{L}$ & pistola & $\mathrm{e}$ & $\mathrm{f}$ & 7 & 3 & 28 & $\mathrm{~L}$ \\
\hline muñequito & $\mathrm{i}$ & & 9 & 4 & 3 & L & \multicolumn{7}{|c|}{ ADJECTIVES } \\
\hline palos & k & & 5 & 2 & 2 & L & & $f$ & & 7 & 3 & 1 & $\mathrm{~L}$ \\
\hline pedazo & f & & 6 & 3 & 1 & L & $\begin{array}{l}\text { abierta } \\
\text { alto }\end{array}$ & $\mathrm{k}$ & & 4 & 2 & 1 & $\begin{array}{l}\mathrm{L} \\
\mathrm{L}\end{array}$ \\
\hline pelota & $\mathrm{c}$ & $\mathrm{e}$ & 6 & 3 & 134 & L & $\begin{array}{l}\text { alto } \\
\text { amarillito }\end{array}$ & $\begin{array}{l}k \\
f\end{array}$ & & 10 & 5 & 2 & L \\
\hline pelotica & e & e & 8 & 4 & 26 & L & amarillito & f & & 10 & 4 & 2 & $\mathrm{~L}$ \\
\hline piñata & $\mathrm{h}$ & & 6 & 3 & 3 & L & amarillo & d & g & 8 & 4 & 50 & $\mathrm{~L}$ \\
\hline plastilina & $\mathrm{i}$ & & 10 & 4 & 5 & $\mathrm{~L}$ & azul & d & e & 4 & 2 & 20 & A \\
\hline salvavidas & $\mathrm{h}$ & & 10 & 4 & 1 & $\mathrm{~L}$ & azulito & $\mathrm{g}$ & & 7 & 4 & 2 & $\mathrm{~L}$ \\
\hline soguita & $\mathrm{i}$ & & 7 & 3 & 1 & L & blanco & $\mathrm{e}$ & & 6 & 2 & 7 & $\mathrm{~L}$ \\
\hline trompo & $f$ & & 6 & 2 & 3 & $\mathrm{~L}$ & carmelita & $\mathrm{f}$ & & 9 & 4 & 1 & $\mathrm{~L}$ \\
\hline velocipedo & $\mathrm{e}$ & & 10 & 5 & 4 & $\mathrm{E}$ & chico & d & & 5 & 2 & 2 & $\mathrm{~L}$ \\
\hline Trees and Flowers & & & & & & $\mathbf{E}$ & chiquita & $\mathrm{i}$ & $\mathrm{i}$ & 8 & 3 & 15 & $\mathrm{~L}$ \\
\hline flor & $\mathrm{d}$ & $\mathrm{h}$ & 4 & 1 & 21 & $A$ & chiquitica & $\mathrm{k}$ & $\mathrm{k}$ & 10 & 4 & 14 & $\mathrm{~L}$ \\
\hline florecita & $\mathrm{f}$ & $\mathrm{g}$ & 9 & 4 & 10 & $\mathrm{~L}$ & chiquitico & $\mathrm{h}$ & & 10 & 4 & 6 & $\mathrm{~L}$ \\
\hline flores & & & 6 & 2 & 6 & $\mathrm{~L}$ & chiquito & g & g & 8 & 3 & 31 & $\mathrm{~L}$ \\
\hline hojita & $\mathrm{d}$ & & 6 & 3 & 1 & $\mathrm{~L}$ & duro & $\mathrm{i}$ & & 4 & 2 & 1 & $\mathrm{~L}$ \\
\hline mata & d & $\mathrm{h}$ & 4 & 2 & 10 & $\mathrm{~L}$ & fea & $\mathrm{i}$ & & 3 & 2 & 2 & $\mathrm{~L}$ \\
\hline matas & $\mathrm{h}$ & & 5 & 2 & 1 & $\mathrm{~L}$ & feo & e & $\mathrm{f}$ & 3 & 2 & 25 & $\mathrm{~L}$ \\
\hline matica & $\mathrm{k}$ & & 6 & 3 & 5 & $\mathrm{~L}$ & fría & e & & 4 & 2 & 3 & $\mathrm{~L}$ \\
\hline maticas & $\mathrm{k}$ & & 7 & 3 & 2 & $\mathrm{~L}$ & grande & e & $\mathrm{g}$ & 6 & 2 & 115 & $\mathrm{~L}$ \\
\hline rosa & $\mathrm{i}$ & & 4 & 2 & 2 & $\mathrm{~L}$ & grandecito & $\mathrm{k}$ & $\mathrm{k}$ & 10 & 4 & 15 & $\mathrm{~L}$ \\
\hline & & & & & & & grandes & $\mathrm{i}$ & & 7 & 2 & 3 & $\mathrm{~L}$ \\
\hline
\end{tabular}


APPENDIX A (Continued)

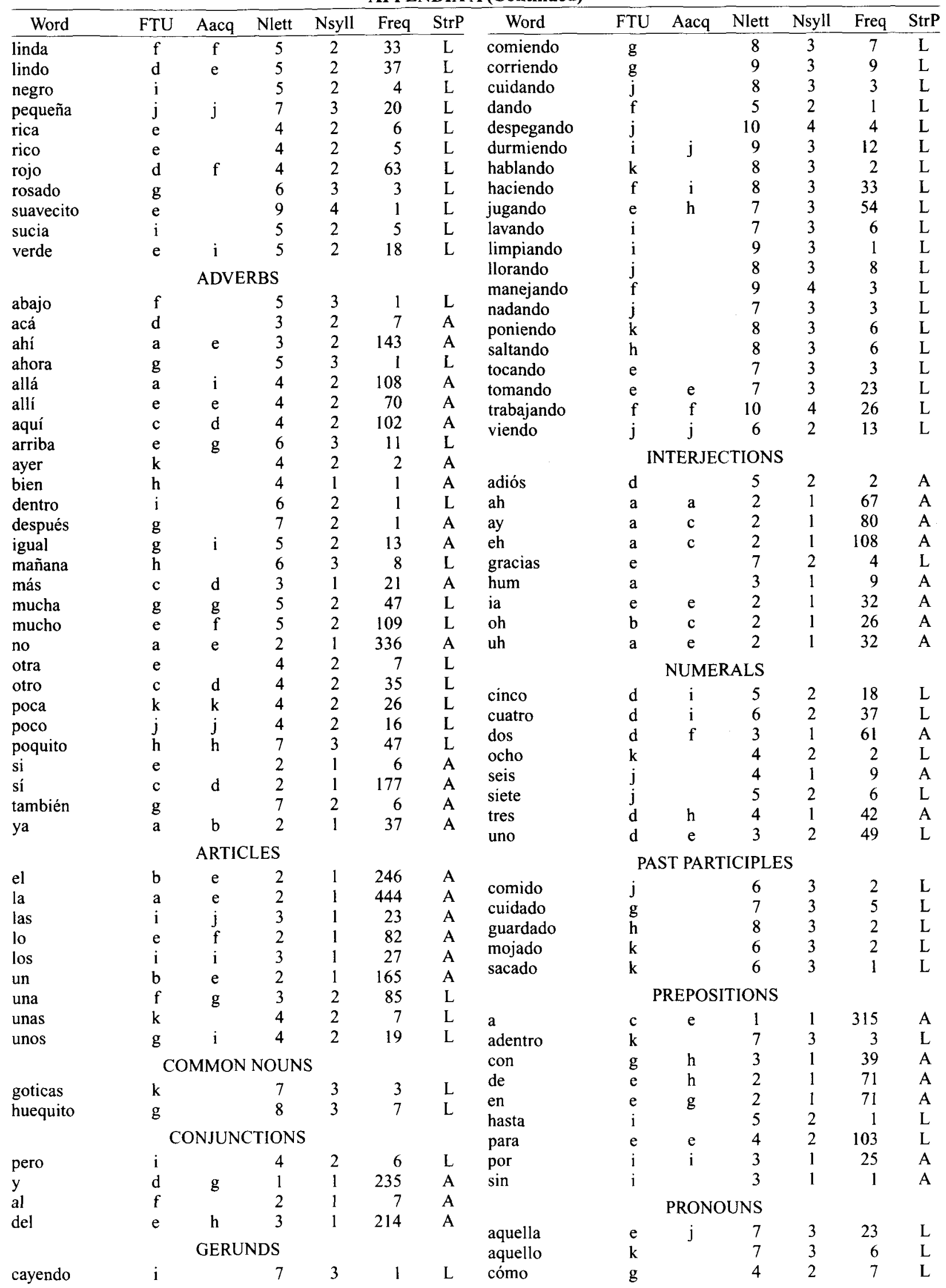


APPENDIX A (Continued)

\begin{tabular}{|c|c|c|c|c|c|c|c|c|c|c|c|c|c|}
\hline Word & FTU & Aacq & Nlett & Nsyll & Freq & StrP & Word & FTU & Aacq & Nlett & Nsyll & Freq & StrP \\
\hline cuándo & $\mathrm{i}$ & & 6 & 2 & 1 & $L$ & chuchi & $\mathrm{k}$ & & 6 & 2 & 2 & $\mathrm{~L}$ \\
\hline dónde & d & e & 5 & 2 & 31 & $\overline{\mathrm{L}}$ & copelia & $\mathrm{h}$ & $\mathrm{h}$ & 7 & 3 & 22 & $\overline{\mathrm{L}}$ \\
\hline él & $\mathrm{g}$ & $\mathrm{g}$ & 2 & 1 & 58 & A & corbata & $\mathrm{i}$ & & 7 & 3 & 1 & $\mathrm{~L}$ \\
\hline ella & $\mathrm{h}$ & $\stackrel{i}{i}$ & 4 & 2 & 30 & L & cristina & $\mathrm{k}$ & & 8 & 3 & 2 & $\mathrm{~L}$ \\
\hline esa & $\mathrm{e}$ & f & 3 & 2 & 87 & L & cuca & f & & 4 & 2 & 2 & $\mathrm{~L}$ \\
\hline ese & d & e & 3 & 2 & 34 & $\mathrm{~L}$ & dairé & h & & 5 & 2 & 1 & A \\
\hline eso & e & $\mathrm{h}$ & 3 & 2 & 59 & L & dalia & g & & 5 & 2 & 2 & L \\
\hline esta & e & f & 4 & 2 & 85 & L & daniel & $\mathrm{f}$ & & 6 & 2 & 1 & A \\
\hline este & c & $\mathrm{e}$ & 4 & 2 & 76 & L & dany & $\mathrm{j}$ & & 4 & 2 & 1 & L \\
\hline esto & c & $\mathrm{e}$ & 4 & 2 & 101 & L & darito & $\mathrm{i}$ & & 6 & 3 & 2 & $\mathrm{~L}$ \\
\hline le & e & $\mathrm{e}$ & 2 & 1 & 17 & A & darivan & $\mathrm{i}$ & & 7 & 3 & 1 & $\mathrm{~L}$ \\
\hline me & $\mathrm{e}$ & $\mathrm{h}$ & 2 & 1 & 143 & A & dayana & i & & 6 & 3 & 1 & $\mathrm{~L}$ \\
\hline $\mathrm{mi}$ & $\mathrm{a}$ & $\mathrm{h}$ & 2 & 1 & 264 & A & deiby & $\mathrm{j}$ & & 5 & 2 & 1 & $\mathrm{~L}$ \\
\hline mía & c & d & 3 & 2 & 103 & $\mathrm{~L}$ & dinet & $\mathrm{j}$ & & 5 & 2 & 1 & A \\
\hline mío & b & e & 3 & 2 & 135 & $\mathbf{L}$ & dinky & e & & 5 & 2 & 2 & A \\
\hline mis & $\mathrm{j}$ & $\mathrm{j}$ & 3 & 1 & 13 & A & dogui & f & & 5 & 2 & 3 & $\mathrm{~L}$ \\
\hline por qué & e & $\mathrm{i}$ & & & 30 & & dory & g & & 4 & 2 & 2 & $\mathrm{~L}$ \\
\hline porque & $\mathrm{g}$ & & 6 & 2 & 4 & L & duni & $\overline{\mathbf{i}}$ & & 4 & 2 & 1 & $\mathrm{~L}$ \\
\hline que & e & $\mathrm{g}$ & 3 & 1 & 39 & A & dunia & $\mathrm{h}$ & & 5 & 2 & 1 & $\bar{L}$ \\
\hline qué & $\mathrm{c}$ & e & 3 & 1 & 70 & A & duxi & $\mathrm{g}$ & & 4 & 1 & 2 & A \\
\hline quién & e & e & 5 & 1 & 25 & A & eduardito & e & & 9 & 4 & 1 & $\mathrm{~L}$ \\
\hline se & d & e & 2 & 1 & 218 & A & eduardo & $\mathrm{k}$ & & 7 & 3 & l & L \\
\hline te & $\mathrm{g}$ & & 2 & 1 & 5 & A & emilio & $\mathrm{h}$ & & 6 & 3 & 1 & $\mathrm{~L}$ \\
\hline tu & $\mathrm{h}$ & & 2 & 1 & 1 & A & enrique & $\mathrm{i}$ & & 7 & 3 & 1 & $\mathrm{~L}$ \\
\hline tú & $\mathrm{g}$ & $\mathrm{h}$ & 2 & 1 & 45 & A & eugenia & k & & 7 & 3 & 1 & $\mathrm{~L}$ \\
\hline tuyo & $\mathrm{e}$ & $\mathrm{h}$ & 4 & 2 & 28 & $\mathrm{~L}$ & eugenio & k & & 7 & 3 & 1 & $\mathrm{~L}$ \\
\hline tuyos & $\mathrm{k}$ & & 5 & 2 & 1 & $\mathrm{~L}$ & expocuba & k & & 8 & 4 & 2 & $\mathrm{~L}$ \\
\hline yo & $\mathrm{c}$ & h & 2 & 1 & 194 & A & fefi & e & & 4 & 2 & 2 & $\mathrm{~L}$ \\
\hline \multicolumn{7}{|c|}{ PROPER NOUNS } & francisco & g & & 9 & 3 & 2 & $\mathrm{~L}$ \\
\hline abel & $\mathrm{e}$ & & 4 & 2 & 1 & A & frank & h & & 5 & 1 & 5 & A \\
\hline abelito & $\mathrm{e}$ & & 7 & 4 & 1 & $\mathrm{~L}$ & frank héctor & $\mathrm{j}$ & & & & 1 & \\
\hline adrián & $\mathrm{e}$ & & 6 & 2 & 1 & A & guanabo & $\mathrm{i}$ & & 7 & 3 & 8 & $\mathrm{~L}$ \\
\hline aida maría & $\mathrm{f}$ & & & & 1 & & habana & $\mathrm{i}$ & & 6 & 3 & 1 & $\mathrm{~L}$ \\
\hline albe & f & & 4 & 2 & 2 & L & ignacio & $\mathrm{i}$ & & 7 & 3 & 1 & L \\
\hline alberto & $\mathrm{e}$ & & 7 & 3 & 2 & $\mathrm{~L}$ & ileana & e & & 6 & 4 & 1 & L \\
\hline alejandro & $\mathrm{j}$ & & 9 & 4 & 1 & L & ily & $\mathrm{f}$ & & 3 & 1 & 2 & A \\
\hline alfre & $\mathrm{f}$ & & 5 & 2 & 2 & $\mathrm{~L}$ & indira & $\mathrm{k}$ & & 6 & 3 & 2 & $\mathrm{~L}$ \\
\hline alfredito & $\mathrm{f}$ & & 9 & 4 & 1 & $\mathrm{~L}$ & isita & $\mathrm{f}$ & & 5 & 3 & 1 & $\mathrm{~L}$ \\
\hline alfredo & $\mathrm{f}$ & & 7 & 3 & 2 & L & jacinto & $\mathrm{h}$ & & 7 & 3 & 1 & $\mathrm{~L}$ \\
\hline amor & $\mathrm{k}$ & & 4 & 2 & 2 & A & joel & k & & 4 & 2 & 1 & A \\
\hline ángela & $\mathrm{g}$ & & 6 & 3 & 2 & E & jorge & $\mathrm{i}$ & & 5 & 2 & 1 & L \\
\hline angelina & $\mathrm{k}$ & & 8 & 4 & 1 & $\mathrm{~L}$ & josé & $\mathrm{e}$ & & 4 & 2 & 3 & A \\
\hline anné & $\mathrm{g}$ & & 4 & 1 & 1 & A & juan & $\mathrm{g}$ & & 4 & 1 & 1 & A \\
\hline annia & $i$ & & 5 & 2 & 1 & $\mathrm{~L}$ & july & $\mathrm{h}$ & & 4 & 2 & 3 & $\mathrm{~L}$ \\
\hline antonio & $\mathrm{k}$ & & 7 & 3 & 1 & $\mathrm{~L}$ & kaki & $\mathrm{j}$ & & 4 & 2 & 2 & $\vec{L}$ \\
\hline any & $\mathrm{e}$ & & 3 & 1 & $i$ & $\mathrm{~A}$ & kenia & $j$ & & 5 & 2 & 1 & L \\
\hline aurorita & $\mathrm{h}$ & & 8 & 4 & $i$ & $\mathrm{~L}$ & kike & $\mathrm{h}$ & & 4 & 2 & 4 & L \\
\hline belascoain & $\mathrm{i}$ & & 10 & 5 & 6 & A & kiki & $\mathrm{g}$ & & 4 & 2 & 2 & L \\
\hline bety & $\mathrm{k}$ & & 4 & 2 & 2 & $\mathrm{~L}$ & lambada & $\dot{j}$ & & 7 & 3 & 4 & $\mathrm{~L}$ \\
\hline caridad & $\mathrm{i}$ & & 7 & 3 & 1 & A & landy & $\mathrm{h}$ & & 5 & 2 & 2 & $\vec{L}$ \\
\hline carlito & $\mathrm{i}$ & & 7 & 3 & 1 & $\mathrm{~L}$ & laurita & $\mathrm{h}$ & & 7 & 3 & 3 & L \\
\hline carlitos & $\mathrm{e}$ & & 8 & 3 & 3 & $\mathrm{~L}$ & layana & $\mathrm{h}$ & & 6 & 3 & 2 & L \\
\hline carlos & $\mathrm{e}$ & & 6 & 2 & 1 & $\mathrm{~L}$ & lázaro & j & & 6 & 3 & 1 & $\mathrm{E}$ \\
\hline cary & $\mathrm{e}$ & & 4 & 1 & 2 & A & leal & $\mathrm{i}$ & & 4 & 2 & 1 & A \\
\hline cecilia & $\mathrm{k}$ & & 7 & 3 & 1 & $\mathrm{~L}$ & lenin & $\mathrm{i}$ & & 5 & 2 & 8 & L \\
\hline césar & $\mathrm{h}$ & & 5 & 2 & 2 & $\mathrm{~L}$ & li & $\mathrm{i}$ & & 2 & 1 & 1 & A \\
\hline chachi & f & & 6 & 2 & 1 & $\bar{L}$ & libia & $\mathrm{j}$ & & 5 & 2 & 1 & L \\
\hline chari & f & & 5 & 2 & 1 & $\mathrm{~L}$ & liena & $i$ & & 5 & 2 & $i$ & $\mathrm{~L}$ \\
\hline charlie & $f$ & & 7 & 2 & 3 & L & lisandra & $\mathrm{i}$ & & 8 & 3 & 3 & $\mathrm{~L}$ \\
\hline chely & $\mathrm{i}$ & & 5 & 2 & 2 & L & loly & $\mathrm{i}$ & & 4 & 2 & 2 & $\mathrm{~L}$ \\
\hline chicho & $\mathrm{g}$ & & 6 & 2 & 1 & $\bar{L}$ & mabelita & $\mathrm{e}$ & & 8 & 4 & 2 & $\mathrm{~L}$ \\
\hline chiqui & $\mathrm{g}$ & & 6 & 2 & 2 & L & maikel & h & & 6 & 2 & 3 & $\mathrm{~A}$ \\
\hline
\end{tabular}


APPENDIX A (Continued)

\begin{tabular}{|c|c|c|c|c|c|c|c|c|c|c|c|c|c|}
\hline Word & FTU & Aacq & Nlett & Nsyll & Freq & StrP & Word & FTU & Aacq & Nlett & Nsyll & Freq & StrP \\
\hline malecón & $\mathrm{j}$ & & 7 & 3 & 2 & $\bar{A}$ & rafi & $\mathrm{j}$ & & 4 & 2 & 2 & $\overline{\mathrm{L}}$ \\
\hline maría & $\mathrm{g}$ & & 5 & 3 & 5 & $\mathrm{~L}$ & rainol & $\mathrm{h}$ & & 6 & 2 & 1 & A \\
\hline marichú & $\mathrm{h}$ & & 7 & 3 & 1 & A & raiza & $\mathrm{j}$ & & 5 & 2 & 2 & $\mathrm{~L}$ \\
\hline mariela & $\mathrm{g}$ & & 7 & 3 & 2 & $\mathrm{~L}$ & ramoncito & $\mathrm{g}$ & & 9 & 4 & 2 & $\mathbf{L}$ \\
\hline marino & f & & 6 & 3 & 1 & $\bar{L}$ & randy & $\mathrm{h}$ & & 5 & 2 & 1 & $\mathbf{L}$ \\
\hline marito & $\mathrm{i}$ & & 6 & 3 & 2 & $\mathrm{~L}$ & raúl & $\mathrm{i}$ & & 4 & 2 & 1 & A \\
\hline marlén & $\mathrm{h}$ & & 6 & 2 & 2 & $\mathrm{~A}$ & raulin & $\mathrm{i}$ & & 6 & 2 & 1 & A \\
\hline marlon & e & & 6 & 2 & 3 & L & reiford & $\mathrm{j}$ & & 7 & 2 & 1 & A \\
\hline marlow & $\mathrm{g}$ & & 6 & 2 & 2 & A & reina & $\mathrm{j}$ & & 5 & 2 & 3 & $\mathrm{~L}$ \\
\hline marta & $\mathrm{h}$ & & 5 & 2 & 1 & $\mathrm{~L}$ & reynol & $\mathrm{j}$ & & 6 & 2 & 2 & A \\
\hline marti & $\mathrm{i}$ & & 5 & 2 & 3 & $\mathrm{~A}$ & roberto & $\mathrm{i}$ & & 7 & 3 & 1 & $\mathrm{~L}$ \\
\hline martina & $\mathrm{g}$ & & 7 & 3 & 3 & L & rosario & $\mathrm{f}$ & & 7 & 3 & 1 & $\mathrm{~L}$ \\
\hline mary & $\mathrm{e}$ & & 4 & 1 & 3 & A & rubén & $\mathrm{g}$ & & 5 & 2 & 1 & A \\
\hline mayi & $\mathrm{k}$ & & 4 & 2 & 1 & L & sairo & $\mathrm{f}$ & & 5 & 2 & 1 & $\mathrm{~L}$ \\
\hline mayo & $\mathrm{h}$ & & 4 & 2 & 1 & $\mathrm{~L}$ & samira & $\mathrm{k}$ & & 6 & 3 & 2 & L \\
\hline mayté & $\mathrm{g}$ & & 5 & 2 & 3 & A & sandra & $\mathrm{f}$ & & 6 & 2 & 1 & $\mathrm{~L}$ \\
\hline mery & $\mathrm{k}$ & & 4 & 2 & 2 & L & sandrita & $\mathrm{f}$ & & 8 & 3 & $i$ & $\mathrm{~L}$ \\
\hline mica & e & & 4 & 2 & 2 & $\mathrm{~L}$ & sandry & g & & 6 & 2 & 2 & $\mathrm{~L}$ \\
\hline miguelito & $\mathrm{e}$ & & 9 & 4 & 2 & $\mathrm{~L}$ & savy & $\mathrm{h}$ & & 4 & 2 & 1 & $\mathrm{~L}$ \\
\hline mikelín & $\mathrm{k}$ & & 7 & 3 & 1 & $\mathrm{~A}$ & severo & $\mathrm{h}$ & & 6 & 3 & 1 & $\mathrm{~L}$ \\
\hline milagrito & $f$ & & 9 & 4 & 3 & $\mathrm{~L}$ & silvio & $\mathrm{j}$ & & 6 & 2 & 2 & $\mathrm{~L}$ \\
\hline mily & $\mathrm{h}$ & & 4 & 2 & 1 & $\mathrm{~L}$ & sisi & $\mathrm{f}$ & & 4 & 2 & 1 & $\mathrm{~L}$ \\
\hline miriam & $\mathrm{j}$ & & 6 & 2 & 1 & A & sochi & e & & 5 & 2 & 2 & $\mathrm{~L}$ \\
\hline mirita & $\mathrm{e}$ & & 6 & 3 & 3 & $\mathrm{~L}$ & sofi & $\mathrm{e}$ & & 4 & 2 & 1 & $\mathrm{~L}$ \\
\hline mirta & $\mathrm{j}$ & & 5 & 2 & 3 & $\mathrm{~L}$ & sofia & $\mathrm{e}$ & & 5 & 3 & 1 & $\mathrm{~L}$ \\
\hline mochi & $\mathrm{i}$ & & 5 & 2 & 2 & $\mathrm{~L}$ & taima & $\mathrm{f}$ & & 5 & 2 & 1 & $\mathrm{~L}$ \\
\hline mónica & $\mathrm{g}$ & & 6 & 3 & 4 & $\mathrm{E}$ & taimí & $\mathrm{f}$ & & 5 & 2 & 1 & A \\
\hline moraimita & $\mathrm{g}$ & & 9 & 4 & 1 & $\mathrm{~L}$ & $\operatorname{tani}$ & $\mathrm{g}$ & & 4 & 2 & 2 & L \\
\hline moti & $\mathrm{k}$ & & 4 & 2 & 2 & $\mathrm{~L}$ & teresita & $\mathrm{e}$ & & 8 & 4 & 2 & $\mathrm{~L}$ \\
\hline naila & $\mathrm{k}$ & & 5 & 2 & 2 & L & tico & $\mathrm{i}$ & & 4 & 2 & 2 & $\mathrm{~L}$ \\
\hline nairin & j & & 6 & 2 & 1 & L & tini & $\mathrm{g}$ & & 4 & 2 & 2 & $\mathrm{~L}$ \\
\hline nancita & $\mathrm{k}$ & & 7 & 3 & 1 & L & tintin & $\mathbf{k}$ & & 6 & 2 & 1 & L \\
\hline nancy & e & & 5 & 2 & 3 & A & titica & $\mathrm{g}$ & & 6 & 3 & 2 & $\mathrm{~L}$ \\
\hline nany & $\mathrm{j}$ & & 4 & 2 & 1 & L & tonito & $\mathrm{e}$ & & 6 & 3 & 1 & $\mathrm{~L}$ \\
\hline nenita & $\mathrm{g}$ & & 6 & 3 & 2 & $\mathrm{~L}$ & toqui & $\mathrm{h}$ & & 5 & 2 & 3 & $\mathrm{~L}$ \\
\hline nica & $\mathrm{k}$ & & 4 & 2 & 2 & $\mathrm{~L}$ & toto & $\mathrm{h}$ & & 4 & 2 & 2 & $\mathrm{~L}$ \\
\hline nini & $\mathrm{f}$ & & 4 & 2 & 3 & $\mathrm{~L}$ & tribilín & $\mathrm{h}$ & & 8 & 3 & 1 & A \\
\hline noel & f & & 4 & 2 & 2 & $\mathrm{~A}$ & varadero & $\mathrm{k}$ & & 8 & 4 & 2 & $\mathrm{~L}$ \\
\hline noni & $\mathrm{e}$ & & 4 & 2 & 1 & $\mathrm{~L}$ & victoria & $\mathrm{k}$ & & 8 & 3 & 1 & $\mathrm{~L}$ \\
\hline norma & $\mathrm{j}$ & & 5 & 2 & 1 & $\mathrm{~L}$ & vinagrito & $\mathrm{f}$ & & 9 & 4 & 3 & $\mathrm{~L}$ \\
\hline obel & $\mathrm{f}$ & & 4 & 2 & 2 & A & yadira & $\mathrm{k}$ & & 6 & 3 & 2 & $L$ \\
\hline ofelia & $\mathrm{j}$ & & 6 & 3 & 1 & $\mathrm{~L}$ & yaimeny & $\mathrm{i}$ & & 7 & 3 & 1 & L \\
\hline ofelita & $f$ & & 7 & 4 & 2 & $\mathrm{~L}$ & yakie & $\mathrm{i}$ & & 5 & 2 & 2 & L \\
\hline omar & $\mathrm{i}$ & & 4 & 2 & 1 & A & yandra & e & & 6 & 2 & 2 & $\mathbf{L}$ \\
\hline onett & $\mathrm{g}$ & & 5 & 2 & 1 & A & yania & $\mathrm{h}$ & & 5 & 2 & 2 & $\mathrm{~L}$ \\
\hline orlandito & $\mathrm{h}$ & & 9 & 4 & 1 & $\mathrm{~L}$ & yaqui & $\mathrm{f}$ & & 5 & 2 & 6 & $\mathrm{~L}$ \\
\hline osvaldito & j & & 9 & 4 & 1 & $\mathrm{~L}$ & yasel & $\mathrm{h}$ & & 5 & 2 & 4 & A \\
\hline paco & $\mathrm{g}$ & & 4 & 2 & 1 & L & yasnai & $\mathrm{h}$ & & 6 & 2 & 1 & $\mathrm{~L}$ \\
\hline paquito & $\mathrm{g}$ & & 7 & 3 & 1 & L & yeni & $\mathrm{i}$ & & 4 & 2 & 1 & $\mathrm{~L}$ \\
\hline patricia & $\mathrm{g}$ & & 8 & 3 & 2 & $\mathrm{~L}$ & yoan & $\mathrm{h}$ & & 4 & 2 & 2 & $\mathbf{L}$ \\
\hline paula & $\grave{j}$ & & 5 & 2 & 1 & $\mathrm{~L}$ & yohandri & $\mathrm{i}$ & & 8 & 3 & 6 & $\mathrm{~L}$ \\
\hline pedrito & $\mathrm{e}$ & & 7 & 3 & 1 & $\mathrm{~L}$ & yolepsi & $\mathrm{g}$ & & 7 & 3 & 1 & $\mathrm{~L}$ \\
\hline pigue & $\mathrm{k}$ & & 5 & 2 & 2 & $\mathrm{~L}$ & yoly & $\mathrm{g}$ & & 4 & 2 & 1 & $\mathrm{~L}$ \\
\hline piky & $\mathrm{i}$ & & 4 & 2 & 1 & $\mathrm{~L}$ & yona & $\mathrm{h}$ & & 4 & 2 & 1 & $\mathrm{~L}$ \\
\hline pili & f & & 4 & 2 & 1 & $\mathrm{~L}$ & yoni & $\mathrm{e}$ & & 4 & 2 & 2 & $\mathrm{~L}$ \\
\hline pirito & $\mathrm{k}$ & & 6 & 3 & 2 & L & yori & $\mathrm{j}$ & & 4 & 2 & 2 & $\mathrm{~L}$ \\
\hline pochi & $\mathrm{k}$ & & 5 & 2 & 3 & $\overline{\mathrm{L}}$ & yosito & $\mathrm{j}$ & & 6 & 3 & 1 & L \\
\hline pucho & $\mathrm{e}$ & & 5 & 2 & 2 & $\mathrm{~L}$ & yumurí & $\mathrm{k}$ & & 6 & 3 & 2 & A \\
\hline quintín & & & & & & & yuni & $\mathrm{f}$ & & 4 & 2 & 3 & $\mathrm{~L}$ \\
\hline banderas & $\mathrm{i}$ & & & & 1 & & yunia & $\mathrm{h}$ & & 5 & 2 & 1 & $\mathrm{~L}$ \\
\hline rafa & $\mathrm{h}$ & & 4 & 2 & 1 & $\mathrm{~L}$ & yunio & $\mathrm{g}$ & & 5 & 2 & 1 & $\mathrm{~L}$ \\
\hline rafael & $\mathrm{k}$ & & 6 & 3 & 1 & A & yunito & $\mathrm{g}$ & & 6 & 3 & 1 & $\mathrm{~L}$ \\
\hline
\end{tabular}


APPENDIX A (Continued)

\begin{tabular}{|c|c|c|c|c|c|c|}
\hline Word & FTU & Aacq & Nlett & Nsyll & Freq & StrP \\
\hline yusmani & $h$ & & 7 & 3 & 2 & $\mathrm{~L}$ \\
\hline yusy & h & & 4 & 2 & 2 & L \\
\hline yuya & e & & 4 & 2 & 2 & $\mathrm{~L}$ \\
\hline zani & e & & 4 & 2 & 1 & $\mathbf{L}$ \\
\hline zanja & j & & 5 & 2 & 3 & $\bar{L}$ \\
\hline zenia & $\mathrm{e}$ & & 5 & 2 & 5 & $\mathrm{~L}$ \\
\hline zoila & i & & 5 & 2 & 1 & $\mathrm{~L}$ \\
\hline
\end{tabular}

Note-For FTU and Aacq, letters represent the following ranges, in months and days: a, 11.16-14.15; b, 14.16-17.15; c, 17.16-20.15; d, 20.16-22.15; e, 22.16-25.15; f, 26.04-29.16; g, 30.04-33.22; h, 34.07-37.21; i, 38.04-41.23; j, 42.0645.21 ; and $\mathrm{k}, 46.03-49.16$.

\section{APPENDIX B}

Stable Substitutes and Their First Time Uttered (FTU), Age of Acquisition (Aacq), and Frequency (Freq)

\begin{tabular}{lccr}
\hline \multicolumn{1}{c}{ Stable Substitute } & FTU & Aacq & Freq \\
\hline au (como hace el perro) & $\mathrm{e}$ & & 4 \\
ca (heces fecales) & $\mathrm{e}$ & $\mathrm{h}$ & 46 \\
caca (prohibición) & $\mathrm{h}$ & & 4 \\
chichi (orine) & $\mathrm{g}$ & & 2 \\
chuchua (sonido del tren) & $\mathrm{e}$ & & 2 \\
croa (como hace la rana) & $\mathrm{e}$ & & 2 \\
cua (pato) & $\mathrm{d}$ & & 2 \\
cua cua (pato) & $\mathrm{b}$ & & 2 \\
gua gua (perro) & $\mathrm{b}$ & $\mathrm{c}$ & 25 \\
gua guau (perro) & $\mathrm{d}$ & $\mathrm{d}$ & 26 \\
guau guau (perro) & $\mathrm{e}$ & $\mathrm{e}$ & 29 \\
jau (perro) & $\mathrm{a}$ & & 6 \\
jau jau (perro) & $\mathrm{b}$ & $\mathrm{c}$ & 55 \\
kikiriki (gallo) & $\mathrm{c}$ & & 1 \\
miau (gato) & $\mathrm{c}$ & $\mathrm{d}$ & 24 \\
misu (gato) & $\mathrm{c}$ & $\mathrm{e}$ & 10 \\
mu (vaca) & $\mathrm{b}$ & & 1 \\
pam pam (sonido de un arma) & $\mathrm{e}$ & & 1
\end{tabular}

\section{APPENDIX B (Continued)}

\begin{tabular}{lllr}
\hline \multicolumn{1}{c}{ Stable Substitute } & FTU & Aacq & Freq \\
\hline papa (comida) & e & e & 40 \\
pau (dar golpe) & e & & 8 \\
pau pau (golpe) & c & & 5 \\
pau pau (dar golpes) & f & f & 57 \\
pí (pollo) & c & & 6 \\
pio (pollito) & b & & 3 \\
pio (pollo) & d & & 9 \\
pio pio (pollo) & e & e & 10 \\
pipa (carro) & e & & 1 \\
pipi (carro) & b & c & 10 \\
pipi (orine) & e & e & 43 \\
pu (carro) & b & e & 25 \\
pu pú (carro) & a & & 2 \\
pua (pelota) & b & & 1 \\
pum (algo que cae) & c & & 5 \\
pun (tirar) & g & g & 29 \\
pun (tiro) & f & & 9 \\
pun pun (pelota) & f & f & 12 \\
pun pun (tirar la pelota) & e & & 4 \\
pupú (carrito) & e & & 3 \\
pupu (carro) & d & & 3 \\
sh sh (sonido de cuando se frie) & e & & 1 \\
tic tac (reloj) & a & c & 31 \\
tin tin (tirar la pelota) & e & & 2 \\
tití (pollito) & a & a & 23 \\
titi (pollo) & d & & 5 \\
titi (pollo) & c & c & 25 \\
yaya (golpe) & e & e & 28 \\
\hline
\end{tabular}

Note - For FTU and Aacq, letters represent the following ranges, in months and days: $a, 11.16-14.15 ; b, 14.16-17.15$; c, 17.1620.15 ; d, 20.16-22.15; e, 22.16-25.15; f, 26.04-29.16; g, 30.0433.22 ; and $h, 34.07-37.21$.

(Manuscript received June 10, 1999; revision accepted for publication May 27, 2000.) 